Professor Smith is survived by his wife, Margaret M. Smith, who was his close collaborator in the field and laboratory, and who was responsible for most of the illustrations in his many papers.

P. H. GREenWOOD

\section{Professor George Macdonald}

Professor George Macdonald, one of the most dominant figures in the world of tropical medicine for twenty years, died on December 10, 1967, in University College Hospital.

The son of John Smyth Macdonald, FRS, Professor of Physiology at Sheffield and later at Liverpool, George Macdonald graduated M.B., Ch.B. at Liverpool University in 1924 at the age of 21 and took his D.T.M. in the same year. In 1925 he went as a research assistant to the Sir Alfred Jones Laboratory at Freetown, Sierra Leone, and in 1926 he published the first of his many papers on malaria. After graduating M.D. Liverpool and taking the London D.P.H. in 1932, he spent seven years in India and Ceylon and returned to England as assistant director of the Ross Institute in 1939. He joined the Royal Army Medical Corps and after a short period as D.A.D.H. Salisbury Plain Area he was appointed to form and command the first Malaria Field Laboratory. This unit had an adventurous career in Greece and Crete.

In 1942 he was appointed consultant malariologist to the Middle East Forces, and his advice saved the Eighth Army from burdening itself with hundreds of tons of antimalarial equipment during its advance to Tripoli. In 1947 he became the first professor of tropical hygiene at the London School of Hygiene and Tropical Medicine, and director of the Ross Institute.

He was a pioneer throughout his life. In Ceylon he devised an automatically flushing siphon for antimalarial drainage, the appearance of which was followed by a spate of "new and improved models". In London, when he turned his mind to the quantitative epidemiology of malaria, the answers to entomological questions he posed were not available; his reaction was to set up the Ross Institute's own entomological unit, now an established leader in research on anophelines. In 1957 he published his collected malariological work in The Epidemiology and Control of Malaria (O.U.P.), a book which mathematicians and others could read with equal pleasure and profit. He was a member of the World Health Organization's Expert Committee on Malaria from its inception, and (theoretical though his work seemed to some people) on several occasions he reasoned out epidemiological methods with strictly practical field application.

The epidemiology of malaria, an asexual infection in man, involved relatively simple mathematical calculations which were soluble with hand calculators - and with help from professional statisticians which he freely acknowledged. When he turned his mind to helminthic and therefore sexual infections the aid of a computer was needed. Characteristically, he learned to produce his own programmes and in due course published a mathematical model for the epidemiology of schistosomiasis. This too has thoroughly practical implications, not least in initiating healthy controversy in a new subject.

As a teacher Macdonald tended to lecture above cloud level. But his formidable brainpower and concentration were freely available to anyone who went to his office, and he solved the problems of hundreds of callers, correspon. dents and committees. He met the knowledge of impending death with great mental and physical courage, carrying on creative work and inspiring others to the last possible moment.

He was made C.M.G. in 1953, and received the Darling Foundation Award in 1954 and the Bernhard Nocht Medal in 1963. He was president of the Royal Society of Tropical Medicine and Hygiene in 1965-67.

$$
\text { B. B. WADDY }
$$

\section{Professor Frank Raw}

Professor Frank Raw died suddenly, in his fortyseventh year, on October 1, 1967, in Brisbane. He had been professor of entomology in the University of Queensland, Australia, for six months.

Graduating from Queen Mary College, University of London, in 1942, Raw began research in Cambridge under Salt and Hollick with the war-time team studying wireworms in agriculture, work which included pioneer studies of the gencral arthropod fauna of pasture and arable soils - a subject that remained Raw's chief interest. After two years he became an advisory entomologist at the Research Station, Long Ashton, later transferring to the National Agricultural Advisory Service, where he continued his work on insects of pasture soils with a broad ecological study of the garden chafer beetle.

In 1948 Raw joined the staff of Rothamsted Experimental Station, and remained there until 1967, specializing in the agricultural aspects of soil zoology. During this period, however, he spent two years at the West African Cocoa Research Station, in what was then the Gold Coast, studying the control of cacao capsids with chlorinated hydrocarbon insecticides; this early work has since led to much improvement in cacao growing.

Raw's work very successfully combined fundamental and practical approaches, and his zoological studies were always related to the effects of soil animals on the yield of crops, an aspect of research in agricultural entomology still much neglected. He continued to study the biology of wireworms at Rothamsted and he made experiments in collaboration with the insecticides department on the chemical control of these pests especially with chlorinated hydrocarbon seed-dressings; this notably contributed to current methods of control. Nevertheless, he also studied side-effects both of chlorinated hydrocarbon and of organophosphorus insecticides on the invertebrate animals in the soil. By improving methods of extracting these animals he revealed the unexpected abundance of Protura, a group that had before been considered as being sparse.

Raw's work on earthworms is well known and his technique of using formalin for sampling populations of worms is now a standard method. He showed, especially in apple orchards, how weather and chemical sprays affected the abundance and activity of worms, how these changes affected the burial of fallen leaves and the incorporation of leaves into the soil as nutrients for the trees; this work also raised problems of the removal from orchards of the spores of the fungus causing apple scab when worms buried dead leaves.

In his studies of the wheat-bulb fly, cut short at a most promising stage, he related the population dynamics of the insect to damage done to wheat crops. He studied the effects of fallow, both locally and nationally, of seedrates, tilth, fertilizer treatment and different varieties of wheat on the response of the crop to attack by this pest. Raw was more aware than most workers that the abundance of a pest is only one of the many factors to be considered when studying loss of yield on crops caused by insect attack and that various ecological interactions between crop, pests and associated organisms are important in agricultural entomology. He had a special ability, not common among research entomologists, to see pests in a broad agricultural context. This wide approach is evident in Raw's publications and especially in his joint editing of the recent treatise, Soil Biology.

Raw was, for long, an active officer of the Association of Applied Biologists and for the past seven years its esteemed treasurer.

It was expected that he would influence the subject of agricultural entomology greatly in his new appoint. ment, for his clarity of thought and of exposition was exceptional.

C. G. JOHNSON 